\title{
Seismic Dynamic Damage Characteristics of Vertical and Batter Pile-supported Wharf Structure Systems
}

\author{
Li Jiren ${ }^{1,2 *}$, Song Bo ${ }^{1,2}$ and Cui Jianyu ${ }^{3}$ \\ ${ }^{1}$ School of Civil and Environmental Engineering, University of Science and Technology Beijing, Beijing 100083, China \\ ${ }^{2}$ Beijing International Cooperation Base for Science and Technology-Aseismic Research of the Rail Transit Engineering in the Strong \\ Motion Area, Beijing 100083, China \\ ${ }^{3}$ Engineering Department, Anderson Technology Corporation, Tokyo 1050003, Japan
}

Received 28 July 2015; Accepted 1 October 2015

\begin{abstract}
Considering a typical steel pipe pile-supported wharf as the research object, finite element analytical models of batter and vertical pile structures were established under the same construction site, service, and geological conditions to investigate the seismic dynamic damage characteristics of vertical and batter pile-supported wharf structures. By the numerical simulation and the nonlinear time history response analysis of structure system and the moment-axial force relation curve, we analyzed the dynamic damage characteristics of the two different structures of batter and vertical piles under different seismic ground motions to provide reasonable basis and reference for designing and selecting a pile-supported wharf structure. Results showed that the axial force of batter piles was dominant in the batter pile structure and that batter piles could effectively bear and share seismic load. Under the seismic ground motion with peak ground acceleration (PGA) of $350 \mathrm{Gal}$ and in consideration of the factors of the design requirement of horizontal displacement, the seismic performance of the batter pile structure was better than that of the vertical pile structure. Under the seismic ground motion with a PGA of $1000 \mathrm{Gal}$, plastic failure occurred in two different structures. The contrastive analysis of the development of plastic damage and the absorption and dissipation for seismic energy indicated that the seismic performance of the vertical pile structure was better than that of the batter pile structure.
\end{abstract}

Keywords: Steel pipe pile-supported wharf, Vertical pile structure, Batter pile structure, Seismic dynamic damage, Moment-axial force $(\mathrm{M}-\mathrm{N})$ relation curve

\section{Introduction}

For vertical and batter structure systems of a pile-supported wharf, different dynamic response characteristics and failure mechanisms are shown under seismic ground motion. After the Han-Shin Awaji earthquake in 1995, the earthquake damage of pile-supported wharves was recorded through field investigation of underwater photography and observation of damaged piles that were pulled out. In many earthquake observations, batter pile-supported wharf structures are more vulnerable than vertical pile structures. In the Tianjin Port, 22 pile-supported wharves have been established, and 700 pairs (1400 piles) of batter piles have been set. After the Tangshan earthquake in 1976, about 464 batter piles (more than $30 \%$ of the total) and 306 pile caps (more than $40 \%$ of the total) were broken [1]. The batter pile structures of the Sagar Dweep Port (Sumatra earthquake in 2004) [2] also broke after the earthquake. As batter pilesupported wharves are easily damaged during an earthquake, vertical pile structures are used instead of batter piles in most countries. In the United States, batter pile structures are not adopted for relevant seismic criteria and guidelines.

* E-mail address: lijiren_mail@126.com ISSN: 1791-2377 @ 2015 Kavala Institute of Technology. All rights reserved.
Nevertheless, the seismic performance of batter pile structures cannot be completely denied. For example, after the Loma Prieta earthquake in 1989, the batter pile structure that supported the rail beams of container cranes in the American Oakland Port remained intact and had no seismic damage. At present, the Code for Seismic Design of Water Transport Engineering (JST146-2012) [3] in China retains the design standard of batter pile wharf structures.

Given that wharf structures that accommodate import and export activities are essential to a port transportation system, understanding the performance of wharf structures in a high seismicity area is important. The seismic performance of pile-supported wharf structures has been the subject of a large number of previous studies. Shafieezaedeh et al. [4] studied the fragility of wharf structures for a typical pilesupported wharf and developed a set of fragility curves using a nonlinear model and limit states. Wang et al. [5] adopted the capacity spectrum method to determine the damage state of the target wharf structure and analyzed the uncertainties associated with the capacity spectrum and the thresholds of different damage states. Jaradat et al. [6] studied the documents of seismic, structural, geotechnical, and soilstructure interaction aspects and discussed various studies to support the development of a displacement-based seismic design. Shafieezadeh et al. [7] used a detailed model of a hypothetical wharf, including nonlinearities in piles, piledeck connections, and soil-structure interaction, and the 
study verified that considering a crane may actually amplify the structural wharf response. Thomopoulos et al. [8] proposed a methodology for the performance-based fragility analysis of pile-supported wharves based on nonlinear dynamic analysis. Elahi et al. [9] evaluated a simple approximate pseudostatic method for estimating the maximum internal forces and the horizontal displacements of a pile group located in a soil slope. The applicability of the approach was verified by comparing the experimental shaking table tests and the results of the rigorous analysis of a pile-supported wharf. Amirabadi et al. [10] developed an optimal probabilistic seismic demand model for pilesupported wharves with batter piles and considered that probabilistic seismic demand models were critical components of performance-based seismic design and seismic risk assessment. Shafieezadeh et al. [11] investigated the modal properties and vulnerability of such existing pilesupported marginal wharves using advanced structural and soil modeling procedures to perform 2D nonlinear plane strain seismic analyses using the time histories of ground displacement and excess pore water pressures within the underlying soil embankment. Shafieezadeh et al. [12] also investigated the $3 \mathrm{D}$ nonlinear response of a typical pilesupported container wharf structure in liquefiable embankment soils. In comparison with that of the 2D model, the importance of the 3D response characteristics of the structure was demonstrated. Amirabadi et al. [13] developed an optimal probabilistic seismic demand model for typical pile-supported wharf structures using probabilistic seismic demand analysis. Heidary et al. [14] developed the seismic fragility curves of an idealized pile-supported wharf with batter piles through a practical framework. The FLAC2D model was used, and nonlinear time history analyses were performed to simulate the seismic performance of the wharf structure. An incremental dynamic analysis was also adopted to estimate the seismic demand quantities, and it indicated that fragility curves were useful for seismic risk assessment. Ramirez-Henao et al. [15] obtained estimates of the secondorder lateral stiffness and the lowest buckling axial load of each pile using simple arithmetic calculations and presented application examples to demonstrate the versatility of the method and to compare the results with commercially available finite element software. They found that the buckling axial load of slender waterside piles was smaller than that of short land side piles. However, when the soil was soft, the difference became insignificant.

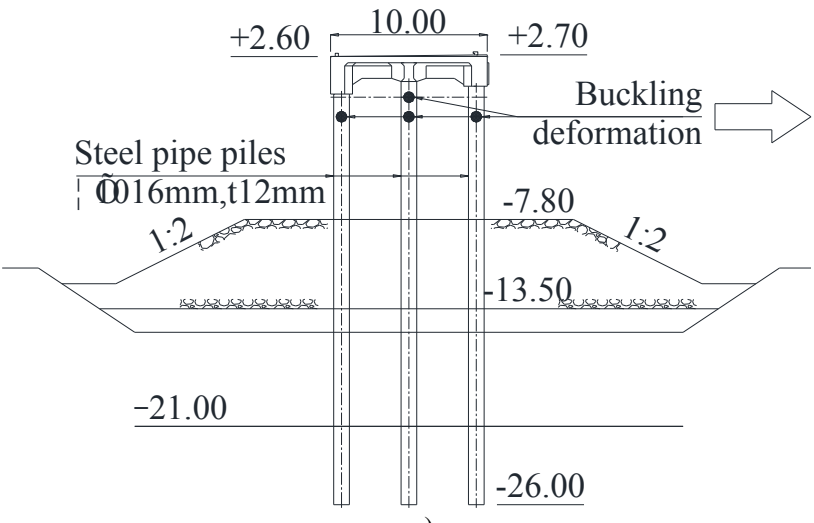

a)

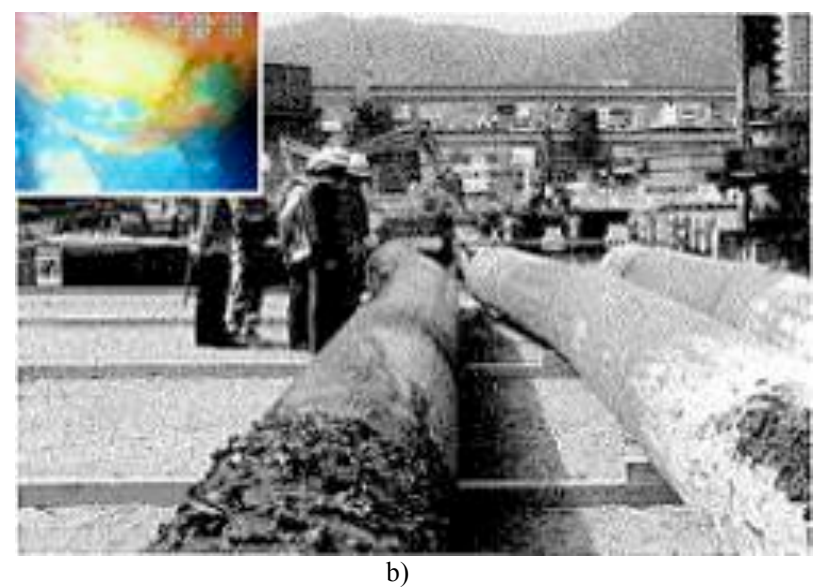

Fig. 1. Wharves damaged by an earthquake (Investigation after the Han-shin Awaji earthquake). (a) Buckling failure location and underwater photography of the damaged piles in the Ofunato Port, (b) Observation of the damaged piles after an earthquake in the Kobe Port

The dynamic damage responses of batter and vertical piles under the same construction site, service, and geological conditions were analyzed in this study. Comparison of the two structures indicated the differences in performance indicators under a seismic action. This study provided reasonable basis and reference for designing and selecting a pile-supported wharf structure.

\section{Research background}

A typical steel pipe pile-supported wharf is selected and studied in this work. The water depth is $-14.0 \mathrm{~m}$, the length in the normal direction is $24.0 \mathrm{~m}$, and the width is $11.0 \mathrm{~m}$. The wharf deck, including slab and beam, is constructed with reinforced concrete. The slab is $400 \mathrm{~mm}$ thick, and the beam is $600 \mathrm{~mm}$ wide and $1000 \mathrm{~mm}$ high. Fig. 2(a) shows the cross-section of a batter pile-supported wharf with two vertical piles and two batter piles. The tilt angle of the batter piles is $13^{\circ}$. The diameter of the vertical pile near the sea side is $600 \mathrm{~mm}$, and its thickness is $9 \mathrm{~mm}$. The other vertical piles are $700 \mathrm{~mm}$ in diameter and $9 \mathrm{~mm}$ in thickness. Fig. 2(b) shows the cross-section of a vertical pile-supported wharf with four vertical piles. The diameter of the vertical pile near the sea side is $600 \mathrm{~mm}$, and its thickness is $9 \mathrm{~mm}$. The other vertical piles are $700 \mathrm{~mm}$ in diameter and $9 \mathrm{~mm}$ in thickness. Steel pipes are SKK400 with yield strength of 235 $\mathrm{N} / \mathrm{mm}^{2}$ regardless of corrosion.

The performance parameters of the steel pipe piles are listed in Table 1.

Table 1. Performance parameters of steel pipe piles

\begin{tabular}{|c|c|c|}
\hline Parameters & $\begin{array}{lll}\text { Steel } & \text { pipe } & \text { pile } \\
\Phi 600 & & \\
\end{array}$ & $\begin{array}{lll}\begin{array}{l}\text { Steel } \\
\text { \$700 }\end{array} & \text { pipe pile } \\
\end{array}$ \\
\hline Diameter $D(\mathrm{~mm})$ & 600 & 700 \\
\hline Thickness $t(\mathrm{~mm})$ & 9 & 9 \\
\hline Circumference $\psi(\mathrm{m})$ & 1.88 & 2.2 \\
\hline Unit weight $w(\mathrm{~kg} / \mathrm{m})$ & 131 & 153 \\
\hline Sectional area $A\left(\mathrm{~m}^{2}\right)$ & $1.671 \mathrm{E}-02$ & $1.954 \mathrm{E}-02$ \\
\hline $\begin{array}{l}\text { Sectional moment of } \\
\text { inertia } I\left(\mathrm{~m}^{4}\right)\end{array}$ & $7.30 \mathrm{E}-04$ & $1.17 \mathrm{E}-03$ \\
\hline Section modulus $Z\left(\mathrm{~m}^{3}\right)$ & $2.43 \mathrm{E}-03$ & 3.33E-03 \\
\hline $\begin{array}{l}\text { Radius of gyration of area } \\
i(\mathrm{~mm})\end{array}$ & 209 & 244 \\
\hline
\end{tabular}


The soil profile for the wharves (Fig. 2) consists of three layers. From GL-4.60 $\mathrm{m}$ to GL-15.0 $\mathrm{m}$ is the riprap layer with N-value of 8 . From GL-15.0 m to GL-18.0 m is the sand soil with N-value of 20. From GL-18.0 m and below is the mudstone with $\mathrm{N}$-value of more than 50 . The $\mathrm{N}$-value of the site soil is measured on the basis of the standard penetration test.

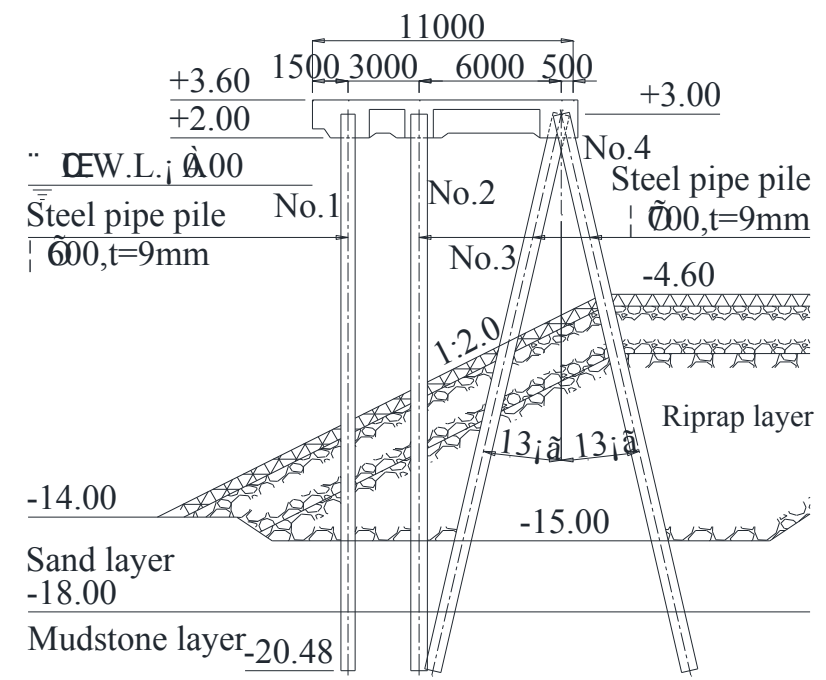

(a) Batter pile-supported wharf (Unit: $\mathrm{mm}$ )

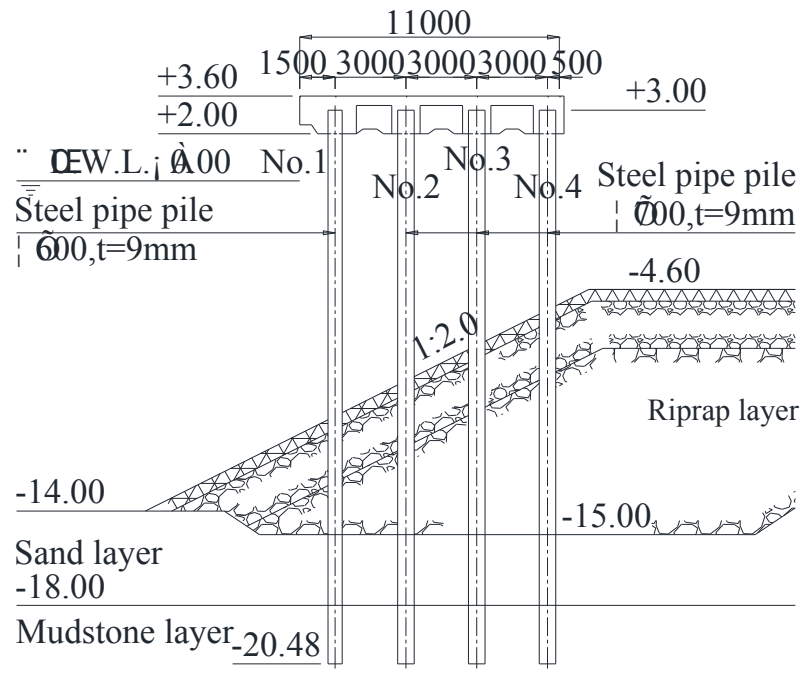

(b) Vertical pile-supported wharf (Unit: $\mathrm{mm}$ )

Fig. 2. Transverse view of the configuration of pile-supported wharf structures

\section{Finite element numerical simulation analysis method}

\subsection{Finite element model}

The finite element models of vertical and batter pilesupported wharf structures are shown in Fig. 3. Nonlinear plastic hinges are set on the connection of the pier concrete slabs and the steel pipe piles to simulate the elastic-plastic response characteristics of the piles under a seismic action to analyze the dynamic damage characteristics of the two different structure systems.

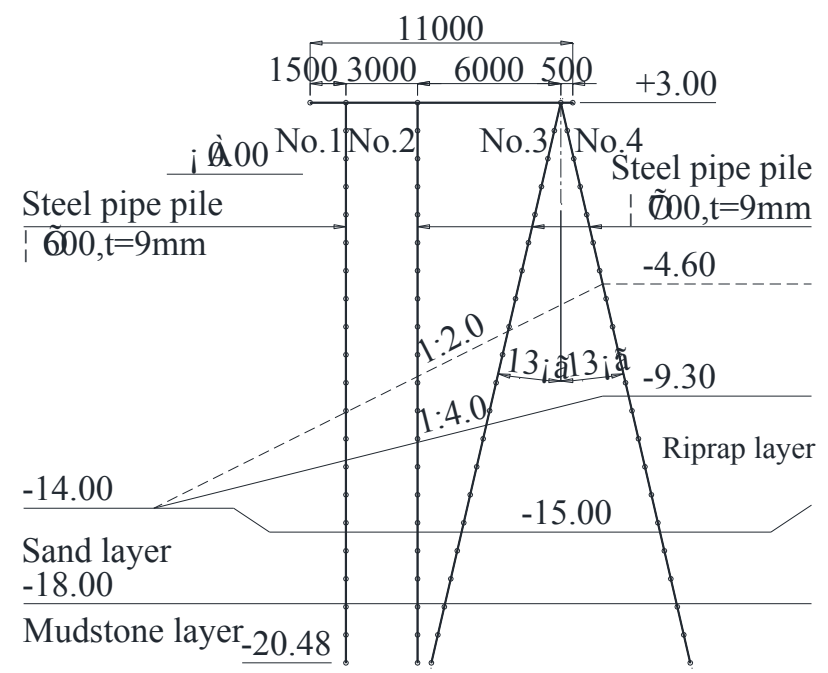

(a) Batter pile-supported wharf (Unit: $\mathrm{mm}$ )

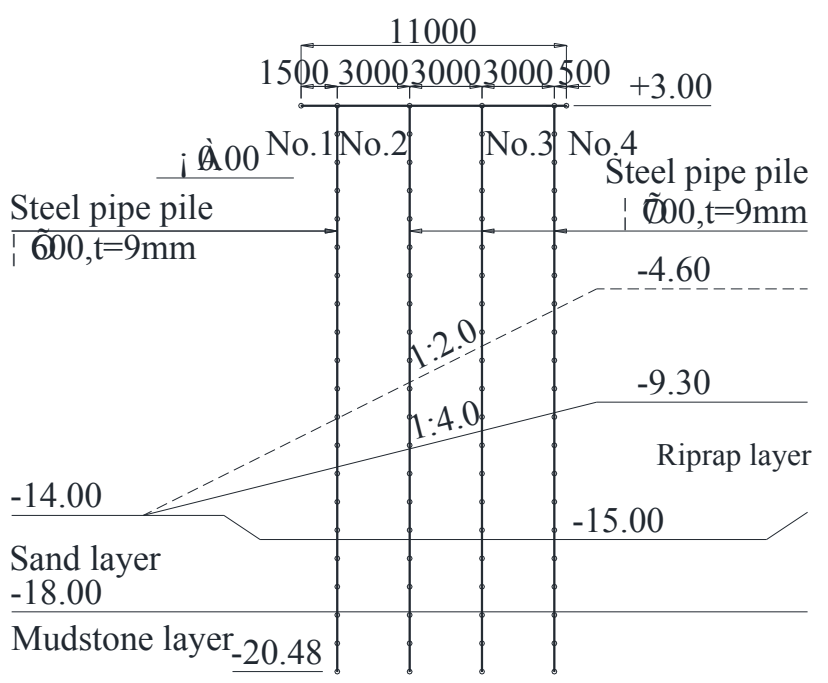

(b) Vertical pile-supported wharf (Unit: $\mathrm{mm}$ )

Fig. 3. Finite element models of pile-supported wharf structures

\subsection{Parameters of soil springs}

The interaction of pile-soil foundation is modeled by a series of soil springs distributed along the length of each of the piles in the directions perpendicular and parallel to the pile axial.

The value of soil spring perpendicular to the direction of the pile axial is determined by Eqs. (1) and (2).

$K_{h}=\alpha \eta_{k} \alpha_{k} k_{h} B_{H}$

$k_{h}=k_{h 0}\left(\frac{B_{H}}{0.3}\right)^{-\frac{3}{4}}$

where $\alpha$ is the correction coefficient of the horizontal foundation reaction by considering the effect of the angle of piles, $\eta_{k}$ is the correction coefficient of the horizontal foundation reaction by considering the effect of pile group and is taken as $1.0, \alpha_{k}$ is the correction coefficient of the horizontal foundation reaction for a single pile and is taken as $1.5, k_{h}$ is the coefficient of the horizontal foundation reaction force during an earthquake $\left(\mathrm{kN} / \mathrm{m}^{3}\right), k_{h 0}$ is the coefficient of the horizontal foundation reaction force $\left(\mathrm{kN} / \mathrm{m}^{3}\right) \quad\left(k_{h 0}\right.$ can be calculated by referring to the 
Specifications for Highway Bridges [16] and be derived through the deformation coefficient $E_{0}=2800 N E_{0}=2800 N\left(\mathrm{kN} / \mathrm{m}^{2}\right), N$ is the $N$-value measured by the standard penetration test.), and $B_{H}$ is the conversion load width of the pile (m). $B_{H}$

The values of the soil spring $K_{S V}$ in the direction of the pile axial and the soil spring of the pile end $K_{V}$ are determined by Eqs. (3) and (4), respectively.

$K_{S V}=0.3 K_{h}$

$K_{V}=\frac{R_{u}}{0.1 D}$

The limit support and the tensile force are determined by Eqs. (5) and (6), respectively:

$P_{N U}=\min \left(R_{u}, R_{p u}\right)$

$$
P_{T U}=\min \left(P_{u}+W, P_{p u}\right)
$$

where $P_{N U}$ is the limit support force; $P_{T U} P_{T U}$ is the limit tensile force; $R_{u} R_{u}$ and $P_{u}$ are the limit support and tensile forces determined by subgrade, respectively; $R_{p u} R_{p u}$ and $P_{p u}$ are the limit pressure $\left(=f_{y} A_{p}=f_{y} A_{p}\right)$ and tensile forces $\left(=f_{y}{ }^{\prime} A_{p}=f_{y}^{\prime} A_{p}\right)$ determined by the piles, respectively; $f_{y} f_{y}$ and $f_{y}{ }^{\prime} f_{y}^{\prime}$ are the compressive and tensile yield strengths of the piles, respectively; $A_{p}$ is the effective sectional area of the steel pipe piles; and $W$ is the sum of the weight of the piles and the effective weight of the soil in the piles.

Based on the parameters determined above, the calculation results of the soil springs perpendicular and parallel to the pile axial direction are shown in Table 2.

Table 2. Performance parameters of soil springs

\begin{tabular}{|c|c|c|c|c|c|}
\hline Steel pipe pile & Diameter $D(\mathrm{~m})$ & Soil layer & $N$-value & $\begin{array}{l}\text { Soil spring perpendicular to } \\
\text { the pile axial direction } \\
\qquad k_{h} \\
(\mathrm{kN} / \mathrm{m})\end{array}$ & $\begin{array}{l}\text { Soil spring parallel to the pile } \\
\text { axial direction } \\
\qquad k_{S V} \\
(\mathrm{kN} / \mathrm{m})\end{array}$ \\
\hline \multirow{3}{*}{ Pile No.1 } & \multirow{3}{*}{0.600} & Riprap & 8 & $1.15 \mathrm{E}+05$ & $3.44 \mathrm{E}+04$ \\
\hline & & Sand & 20 & $2.87 \mathrm{E}+05$ & $8.61 \mathrm{E}+04$ \\
\hline & & Mudstone & 50 & $7.17 \mathrm{E}+05$ & $2.15 \mathrm{E}+05$ \\
\hline \multirow{3}{*}{ Pile No.2 } & \multirow{3}{*}{0.700} & Riprap & 8 & $1.17 \mathrm{E}+05$ & $3.51 \mathrm{E}+04$ \\
\hline & & Sand & 20 & $2.92 \mathrm{E}+05$ & $8.77 \mathrm{E}+04$ \\
\hline & & Mudstone & 50 & $7.31 \mathrm{E}+05$ & $2.19 \mathrm{E}+05$ \\
\hline \multirow{3}{*}{ Pile No. 3 and No. 4} & \multirow{3}{*}{0.700} & Riprap & 8 & $1.24 \mathrm{E}+05$ & $3.72 \mathrm{E}+04(3.51 \mathrm{E}+04)$ \\
\hline & & Sand & 20 & $3.10 \mathrm{E}+05$ & $9.30 \mathrm{E}+04(8.77 \mathrm{E}+04)$ \\
\hline & & Mudstone & 50 & $7.75 \mathrm{E}+05$ & $2.32 \mathrm{E}+05(2.19 \mathrm{E}+05)$ \\
\hline
\end{tabular}

Note: The values in parentheses are the equivalent springs parallel to the pile axial direction of piles No.3 and No.4 in a vertical pile-supported wharf.

\subsection{Selection of input seismic ground motion}

The El Centro seismic ground motion shown in Fig. 4 is used in the nonlinear time history analysis. The peak ground acceleration (PGA) is $356.9 \mathrm{Gal}$, and the duration is $53.72 \mathrm{~s}$. This motion was recorded during the 1940 Imperial Valley earthquake $\left(\mathrm{M}_{\mathrm{s}}=7.2\right)$ in California. The PGA is adjusted to 350 and $1000 \mathrm{Gal}$. The PGA of $350 \mathrm{Gal}$ can be used in the design of harbor structures, and it is equivalent to the seismic ground motion of level I. The ground motion with a PGA of $1000 \mathrm{Gal}$, which is larger than that at level I, is adopted to analyze the plastic characteristics of the steel pipe piles.

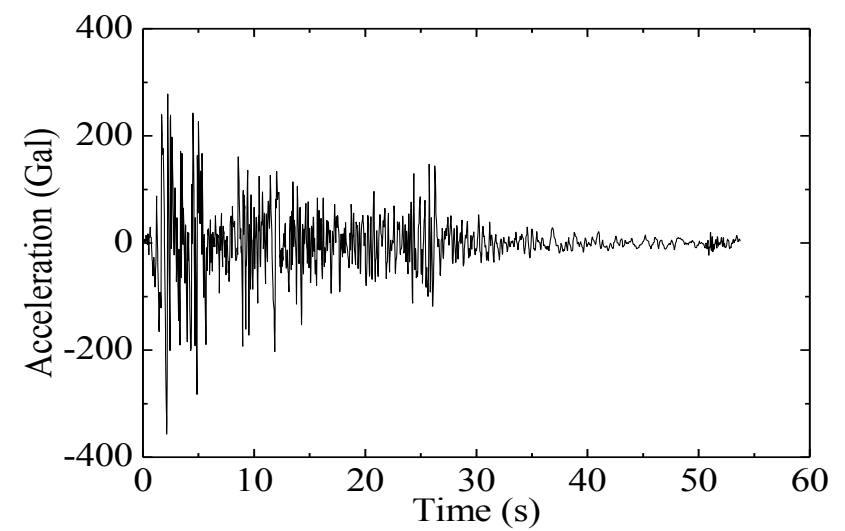

Fig. 4. Accelerogram of the El Centro seismic ground motion

\subsection{Dynamic response numerical calculation method in} finite element analysis

The motion equation of the structure system for the dynamic time history response can be determined by the numerical time-stepping method for integrating differential equations [17]. The Newmark method is adopted for the numerical calculation of the dynamic response. The calculation is based on the following equations:

$\dot{u}_{i+1}=\dot{u}_{i}+[(1-\gamma) \Delta t] \ddot{u}_{i}+(\gamma \Delta t) \ddot{u}_{i+1}$

$u_{i+1}=u_{i}+(\Delta t) \dot{u}_{i}+\left[(0.5-\beta)(\Delta t)^{2}\right] \ddot{u}_{i}+\left[\beta(\Delta t)^{2}\right] \ddot{u}_{i+1}$

where $\ddot{u}, \dot{u}$, and $u u$ are the acceleration, velocity, and relative displacement, respectively.

If the time step satisfies Eq. (9), the Newmark method will be stable.

$$
\frac{\Delta t}{T_{n}} \leq \frac{1}{\pi \sqrt{2}} \cdot \frac{1}{\sqrt{\gamma-2 \beta}}
$$

The parameters $\beta$ and $\gamma$ define the variation in the acceleration in time steps and determine the stability and 
accuracy characteristics of the calculation method. When $\beta=1 / 4 \beta=1 / 4$ and $\gamma=1 / 2 \gamma=1 / 2$, Eq. (9) is expressed as Eq. (10).

$$
\frac{\Delta t}{T_{n}}<\infty
$$

Therefore, Newmark equations are the same as the derived assuming constant average acceleration, which is the average acceleration method. The average acceleration method is stable for any time step. Therefore, the time step does not affect the stability of the dynamic equation solutions.

\section{Simulation analysis of the failure process}

4.1 Dynamic time history response analysis of relative displacement

Figs. 5 and 6 show the results of the pile top relative displacement of the two pile-supported wharf structures under different ground motions. With an increase in PGA, the relative displacement on the pile top also increases.

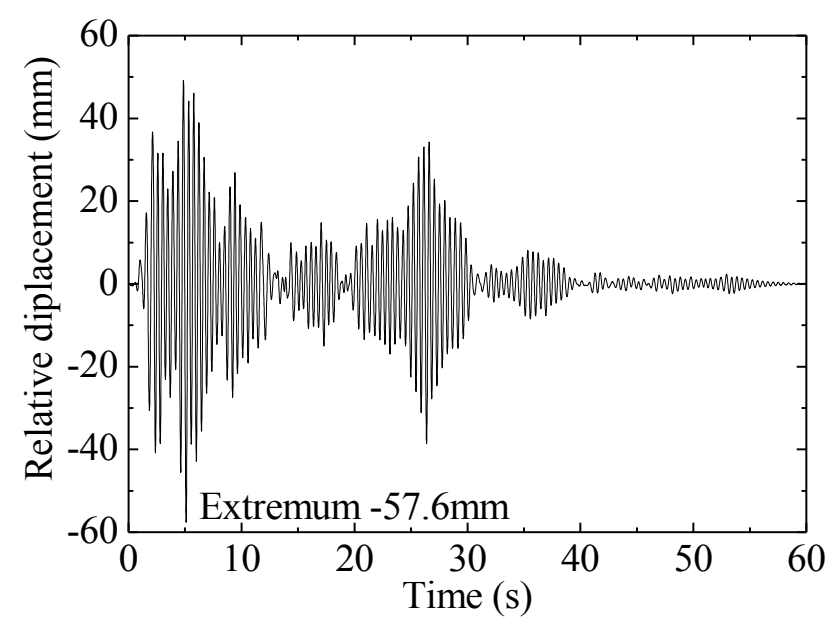

(a) Batter pile-supported wharf structure

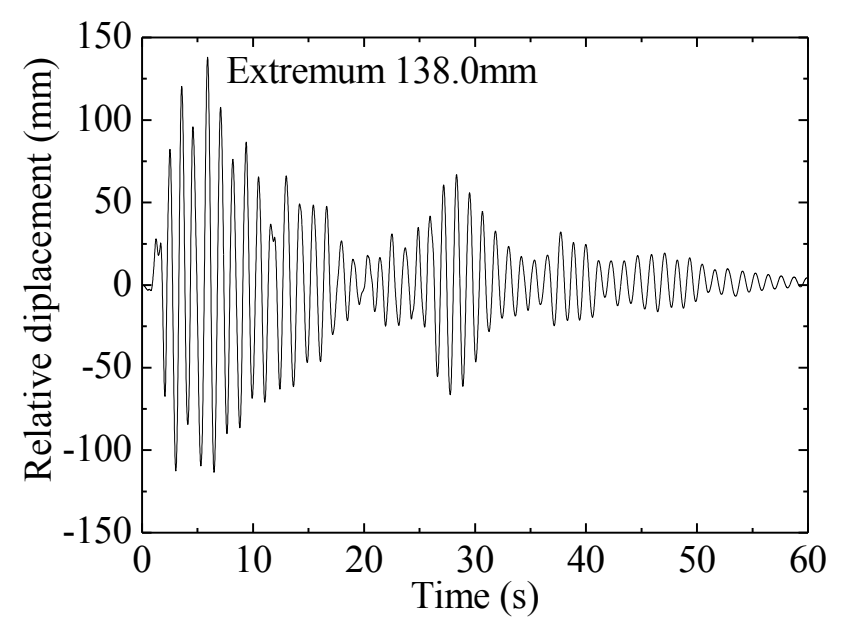

(b) Vertical pile-supported wharf structure

Fig. 5. Relative displacement time histories of the pile top $(\mathrm{PGA}=350$ Gal)

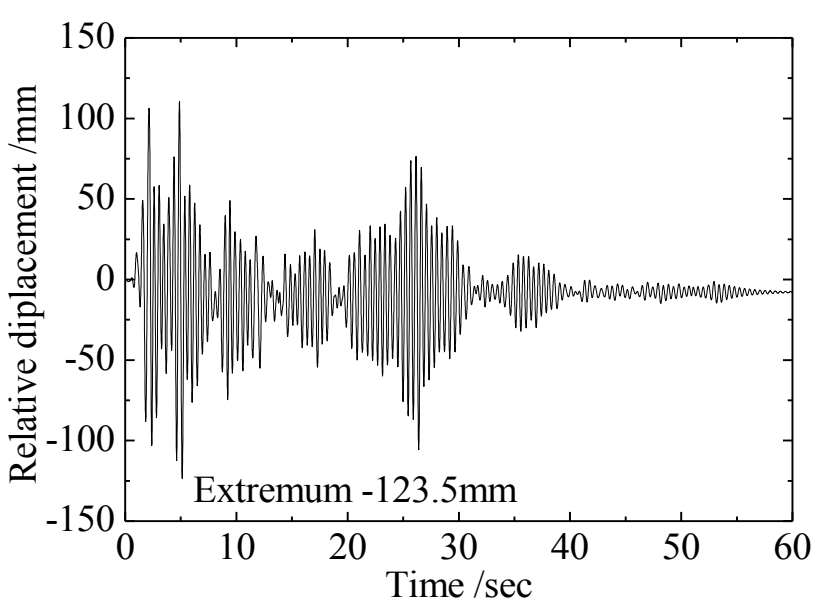

(a) Batter pile-supported wharf structure

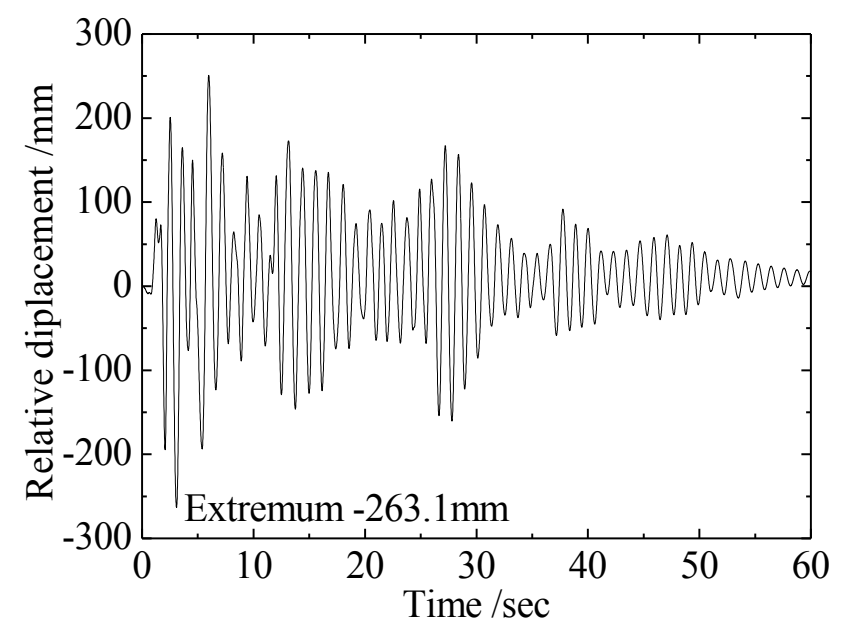

(b) Vertical pile-supported wharf structure

Fig. 6. Relative displacement time histories of the pile top (PGA = $1000 \mathrm{Gal})$

The effect of the maximum displacement under ground motion on the batter pile-supported structure is smaller than that on the vertical pile-supported structure. According to the results of the dynamic time history response analysis, the maximum displacement of the vertical pile-supported structure is more than two times of the batter pile-supported structure. Under the same condition, the displacement performance indicator can be better controlled by the batter pile-supported structure.

4.2 Limit-bearing capacity analysis based on the correlation of moment-axial force (M-N)

The $\mathrm{M}-\mathrm{N}$ relation curves shown in Figs. 7 and 8 indicate that for the vertical pile-supported structure, the variation in the moment value is reciprocating under ground motion, whereas the variation in the axial force value remains in a small scale. The responses of the vertical piles (piles No.1 and No.2) in the batter pile-supported structure show similar variation characteristics. Given that the batter piles (piles No.4 and No.3) bear pressure and tension alternately, the values of the moment and axial forces simultaneously have large changes within a certain range. 

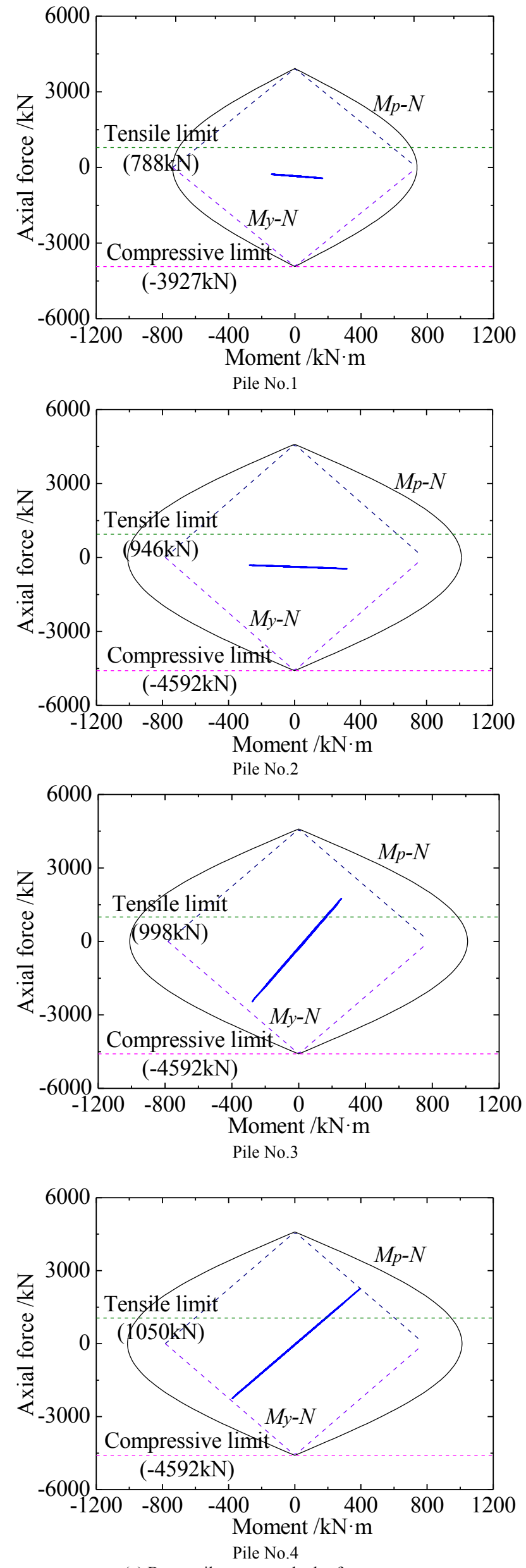

(a) Batter pile-supported wharf structure
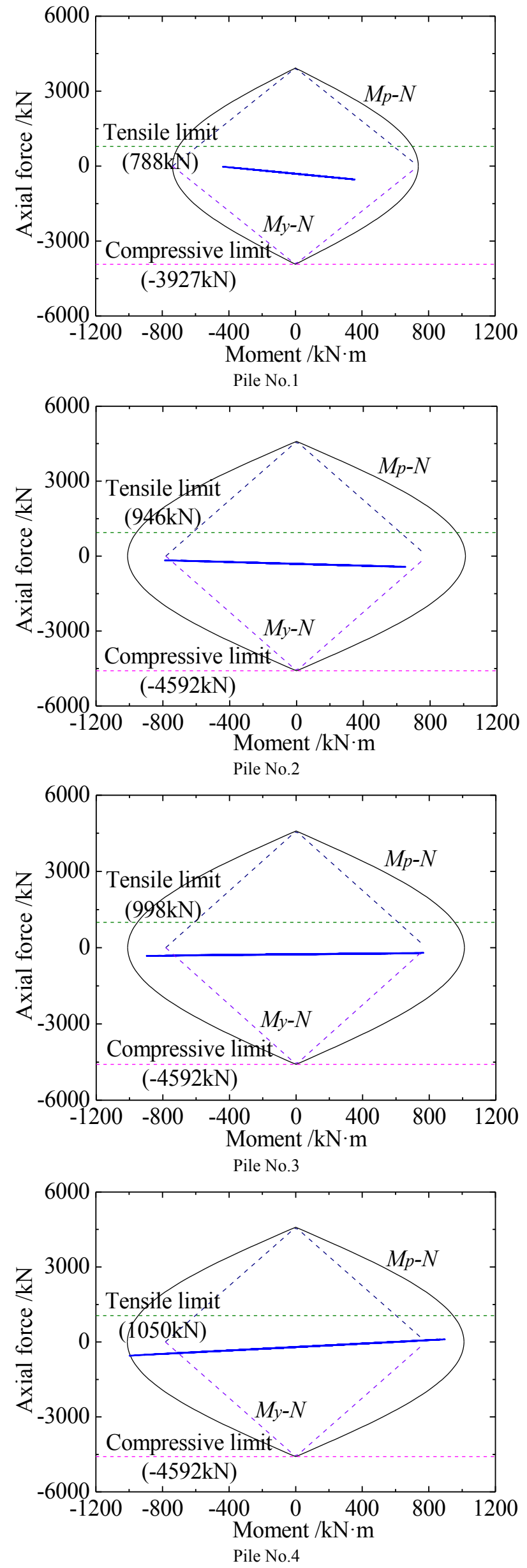

(b) Vertical pile-supported wharf structure

Fig. 7. $\mathrm{M}-\mathrm{N}$ relation curve of the pile top $(\mathrm{PGA}=350 \mathrm{Gal})$ 
Under ground motion with a PGA of $350 \mathrm{Gal}$, the two types of structure systems do not meet the full-plastic area, and plastic damage does not occur. As shown in Fig. 7 (a), the responses of the two batter piles of No.4 and No.3 exceed the tensile limit value but are still in the elastic stage. In Fig. 7 (b), the responses of the three vertical piles of No.4, No.3, and No.2 in the vertical pile-supported structure exceed the elastic stage and are in the plastic area. Therefore, under the seismic ground motion of this level and in consideration of the horizontal displacement to be satisfied by the design requirement, the seismic performance of the batter pile-supported structure is better than that of the vertical pile-supported structure.

Under ground motion with a PGA of $1000 \mathrm{Gal}$, as shown in Fig. 8, the batter piles of the batter pile-supported structure and all the vertical piles of the vertical pile structure exceed the limit load and are in the plastic area. Plastic damage occurs.
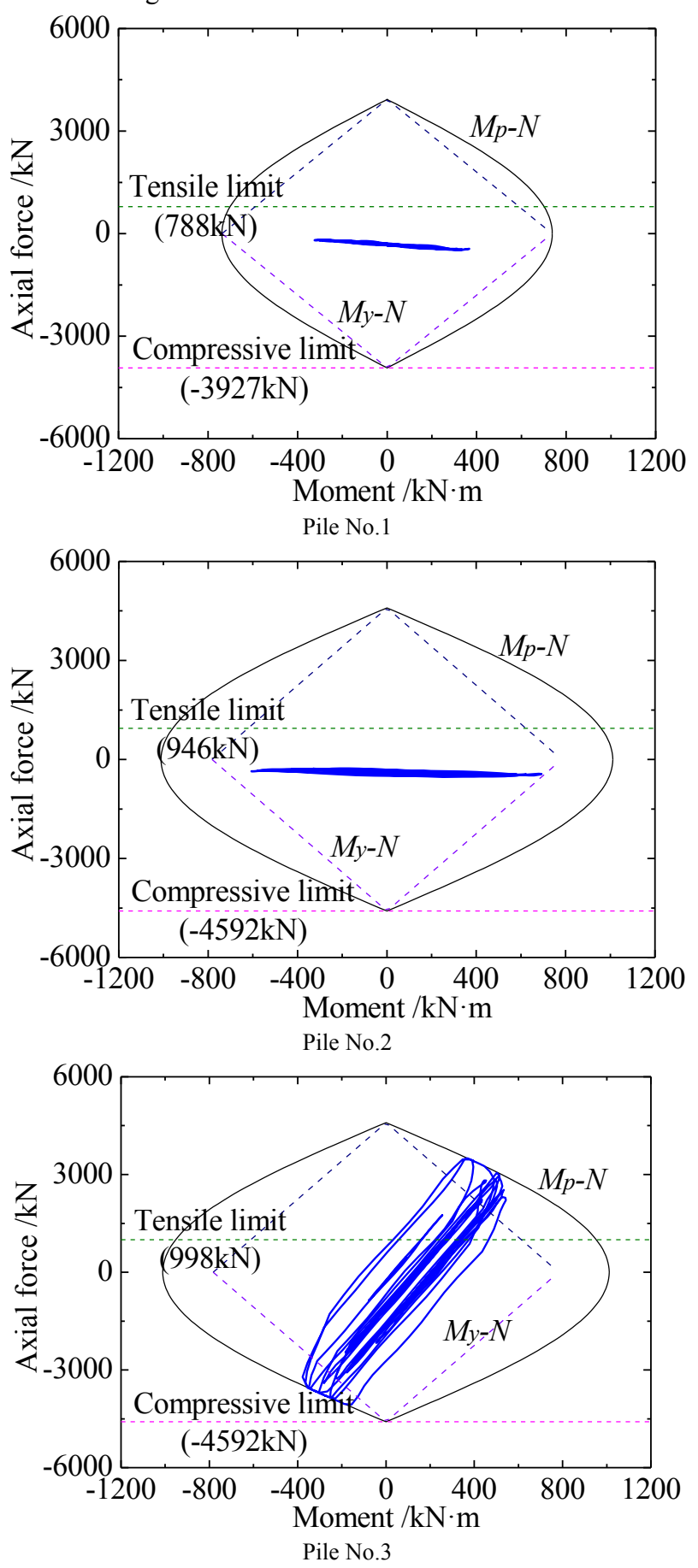

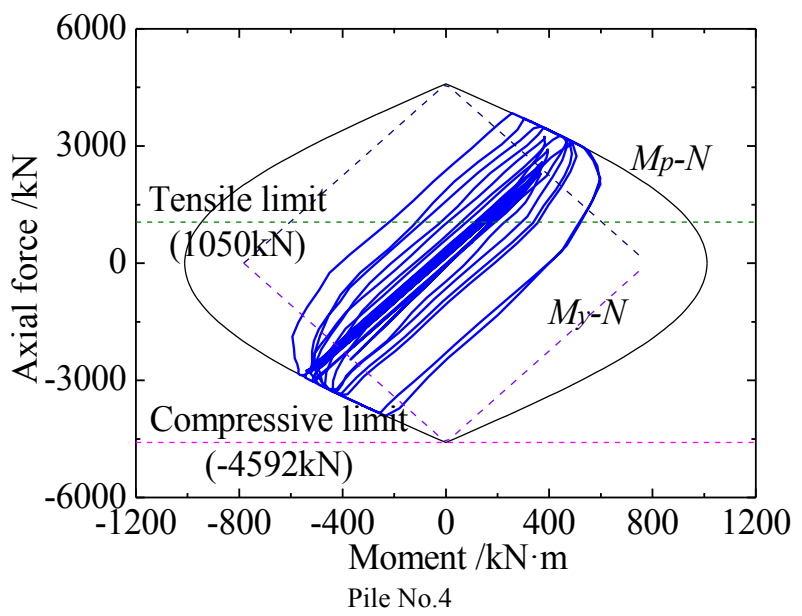

(a) Batter pile-supported wharf structure
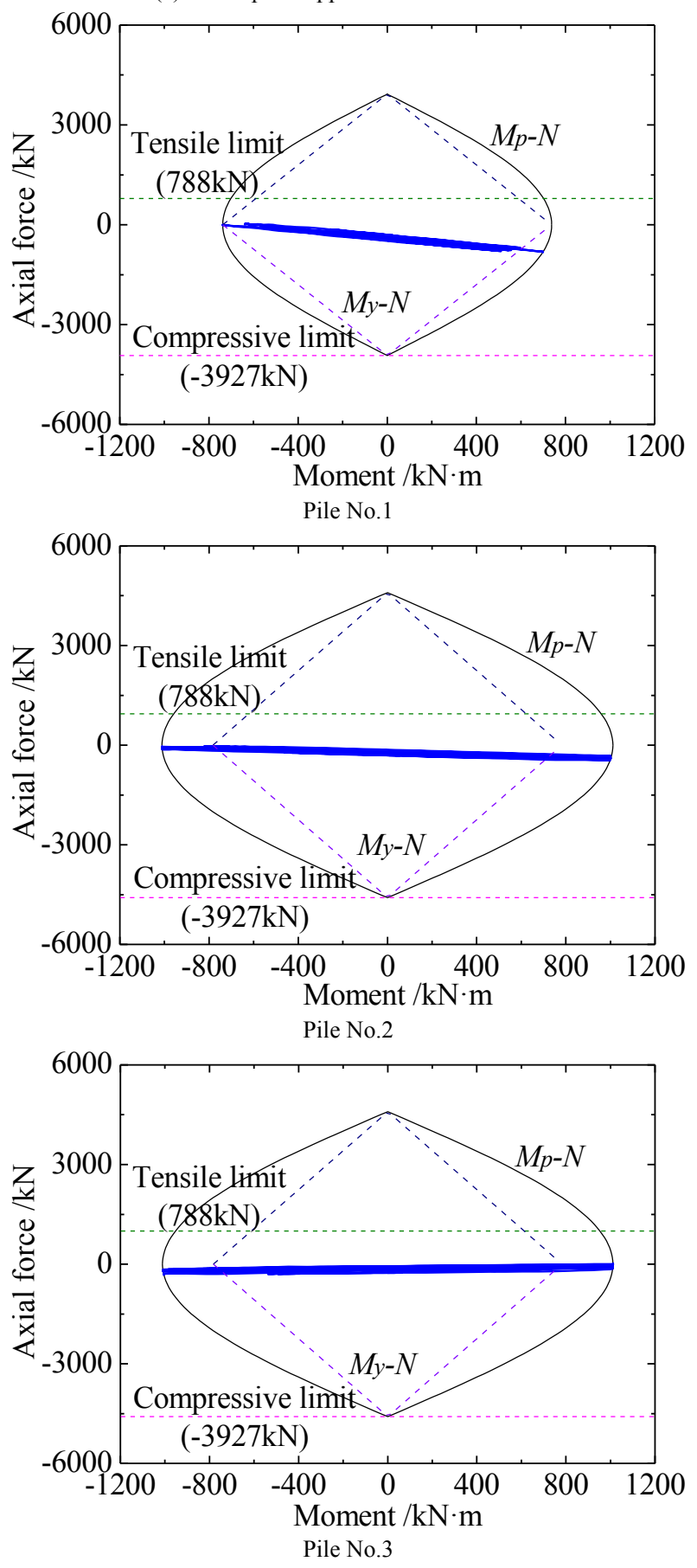


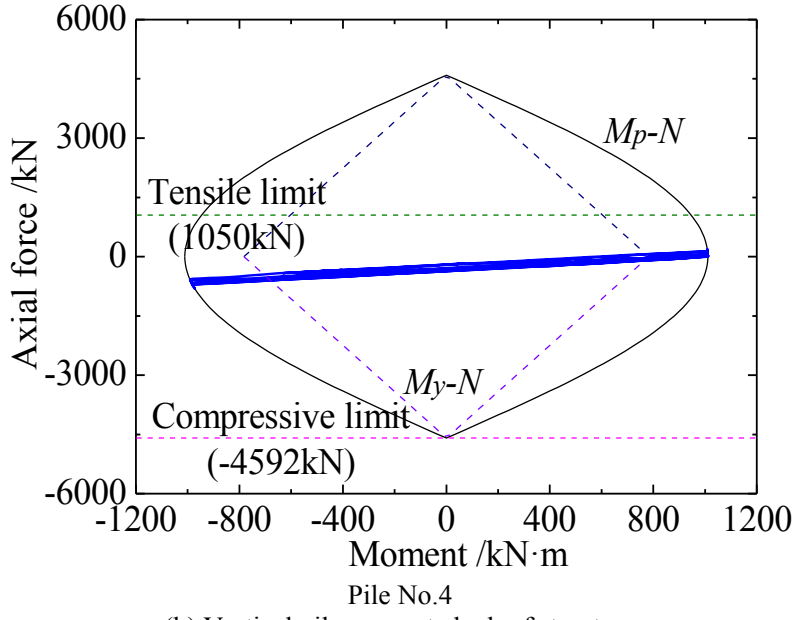

(b) Vertical pile-supported wharf structure

Fig. 8. $\mathrm{M}-\mathrm{N}$ relation curve of the pile top $(\mathrm{PGA}=1000 \mathrm{Gal})$

During the two different types of ground motions, the batter piles in the batter pile-supported structure play a dominant role in bearing the seismic load. Consequently, the vertical piles near the sea side are not in the plastic area, and plastic hinge does not occur. By contrast, all piles in the vertical pile-supported structure enter the plastic area (PGA $=350 \mathrm{Gal})$ or reach full plasticity $(\mathrm{PGA}=1000 \mathrm{Gal})$, and plastic damage occurs. The axial tension and pressure in batter piles play a major role in the batter pile-supported structure. Under the same ground motions, the moment value in the batter pile-supported structure is thus smaller than that in the vertical pile-supported structure. From the $\mathrm{M}-\mathrm{N}$ relation curve, the moment in the vertical pilesupported structure plays a dominant role, and the variation range of the value is larger than that in the batter pilesupported structure.

\subsection{Plastic damage and failure process}

According to the limit-bearing capacity analysis, the sequence and the timing of the pile failure process under seismic ground motion can be obtained and reflected in the acceleration and displacement relation curve, as shown in Fig. 9. With an increase in acceleration and displacement, except the vertical piles in the batter pile-supported structure, the other piles from the land side to the sea side approach the plastic stage sequentially, and plastic damage occurs.

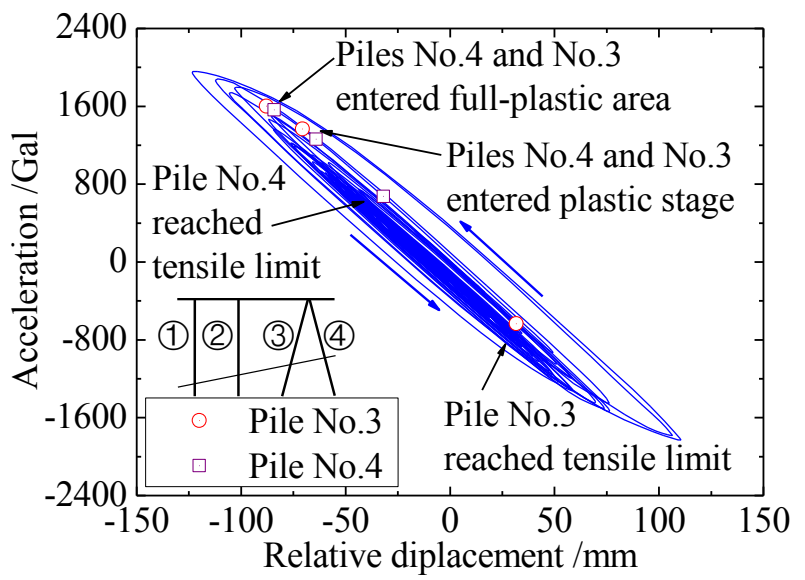

(a) Batter pile-supported wharf structure

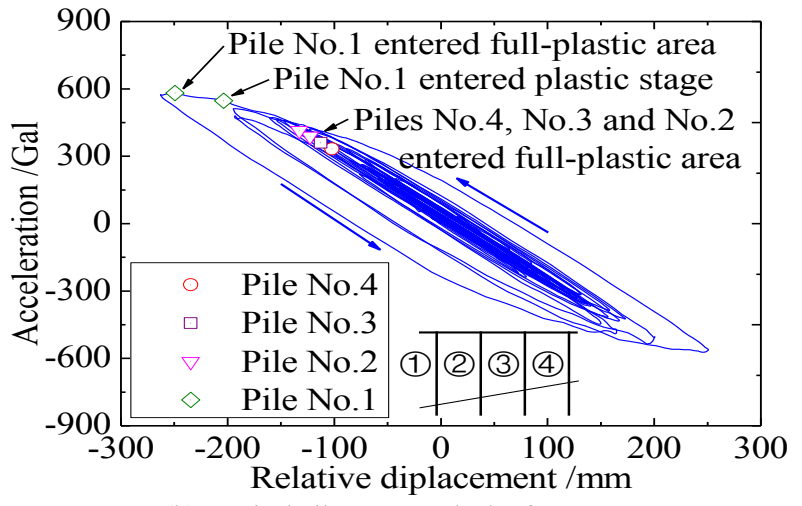

(b) Vertical pile-supported wharf structure

Fig. 9. Acceleration-displacement relation curve of the pile top (PGA = 1000 Gal)

Under ground motion with a PGA of $1000 \mathrm{Gal}$, the batter piles (piles No.3 and No.4) in the batter pile-supported structure reach the tensile limit at accelerations of 630 and $670 \mathrm{Gal}$. When the acceleration of the pile top reaches 1560 and $1600 \mathrm{Gal}$, full plasticity occurs. The timing of the damage and the failure process for the batter piles is shown in Table 3.

Table 3. Timing of the damage development of the batter pile-supported structure $(\mathrm{PGA}=1000 \mathrm{Gal})$

\begin{tabular}{l|c|c|c}
\hline \multicolumn{1}{c|}{ Damage development } & $\begin{array}{c}\text { Time } \\
\text { (s) }\end{array}$ & $\begin{array}{c}\text { Acceleration } \\
\text { (Gal) }\end{array}$ & $\begin{array}{c}\text { Relative } \\
\text { displacement } \\
\text { (mm) }\end{array}$ \\
\hline $\begin{array}{l}\text { (1) Pile No.3 reached the } \\
\text { tensile limit }\end{array}$ & 1.50 & -633 & 31.7 \\
$\begin{array}{l}\text { (2) Pile No.4 reached the } \\
\text { tensile limit }\end{array}$ & 1.74 & 673 & -31.9 \\
$\begin{array}{l}\text { (3) Pile No.4 entered the } \\
\text { plastic stage } \\
\text { (4) Pile No.3 entered the }\end{array}$ & 1.78 & 1262 & -64.2 \\
plastic stage \\
$\begin{array}{l}\text { (5) Pile No.4 entered the } \\
\text { full-plastic area } \\
\text { (6) Pile No.3 entered the } \\
\text { full-plastic area }\end{array}$ & 1.82 & 1368 & -70.6 \\
\end{tabular}

The piles of No.4 and No.3 in the vertical pile-supported wharf approach the plastic stage and enter the full-plastic area, respectively, when the acceleration reaches 330 and $360 \mathrm{Gal}$ approximately. When the acceleration reaches 400 Gal, pile No. 2 reaches the plastic stage and enters the fullplastic area immediately. The pile No.1 near the sea side enters the full-plastic area when the acceleration reaches 580 Gal. The pile top displacement rapidly increases. The timing of the damage and the failure process for the vertical pilesupported structure is shown in Table 4.

Table 4. Timing of the damage development of the vertical pile-supported structure $(\mathrm{PGA}=1000 \mathrm{Gal})$

\begin{tabular}{l|c|c|c}
\hline \multicolumn{1}{c|}{ Damage development } & $\begin{array}{c}\text { Time } \\
\text { (s) }\end{array}$ & $\begin{array}{c}\text { Acceleration } \\
\text { (Gal) }\end{array}$ & $\begin{array}{c}\text { Relative } \\
\text { displacement } \\
\text { (mm) }\end{array}$ \\
\hline $\begin{array}{l}\text { (1) Pile No.4 entered the } \\
\text { full-plastic area } \\
\text { (2) Pile No.3 entered the }\end{array}$ & 1.92 & 332 & -102.1 \\
$\begin{array}{l}\text { full-plastic area } \\
\text { (3) Pile No.2 entered the }\end{array}$ & 1.93 & 360 & -112.6 \\
plastic stage \\
$\begin{array}{l}\text { (4) Pile No.2 entered the } \\
\text { full-plastic area } \\
\text { (5) Pile No.1 entered the } \\
\text { plastic stage } \\
\text { (6) Pile No.1 entered the } \\
\text { full-plastic area }\end{array}$ & 1.95 & 389 & -112.8 \\
\hline
\end{tabular}


Comparison of the damage and the failure process of the two structure systems indicates that the timing of the damage and the failure process of the vertical pile-supported structure is later than that of the batter pile-supported structure. Therefore, the plastic damage that occurs in the batter pile-supported structure is prior to that in the vertical pile-supported structure. Comparison of the momentcurvature $(M-\Phi)$ hysteresis curve of the two structures in Fig. 10 presents that the vertical pile-supported structure has enough capacity for plasticity development to absorb and dissipate seismic energy in contrast to the batter pilesupported structure. Therefore, under the seismic ground motion of this level, the seismic performance of the vertical pile-supported structure is superior to that of the batter pilesupported structure.

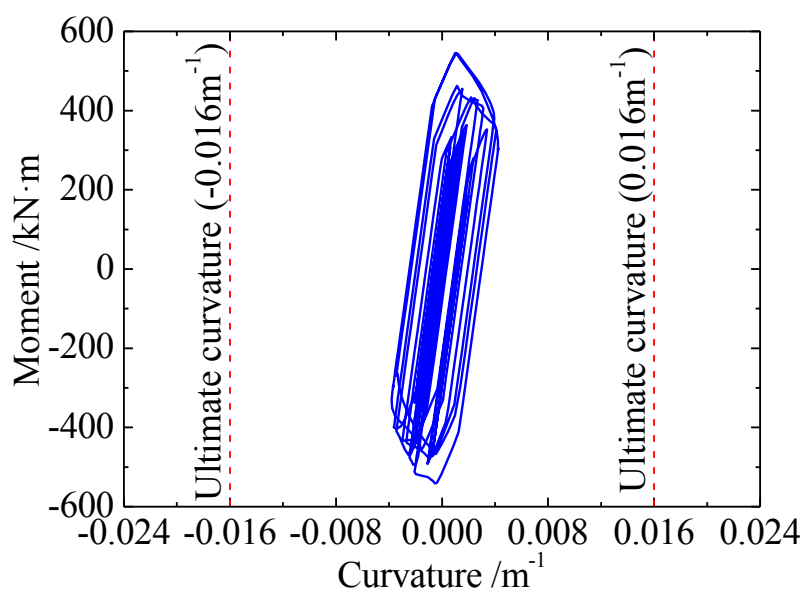

(a) Batter pile-supported wharf structure

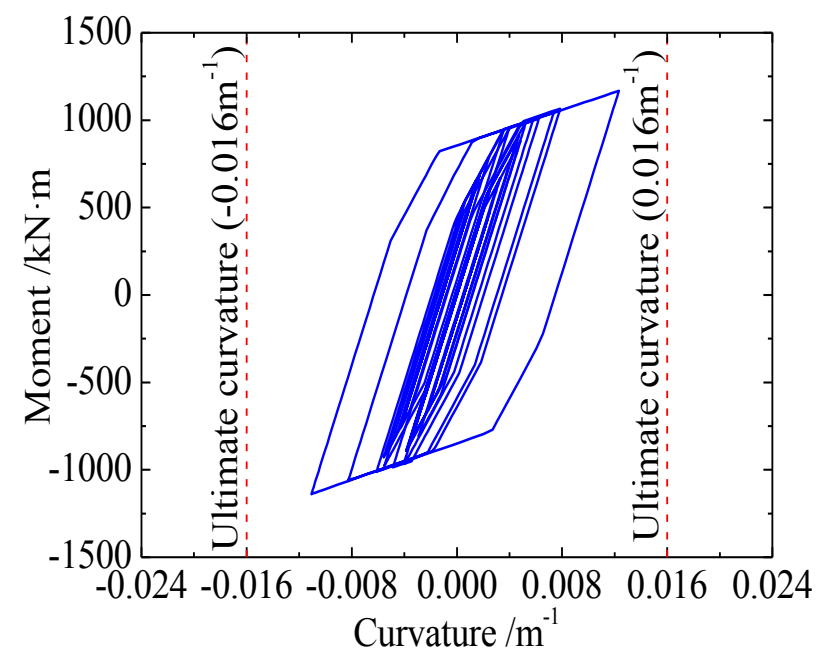

(b) Vertical pile-supported wharf structure

Fig. 10. $M-\Phi$ relation curve of the top of pile No.4 $(\mathrm{PGA}=1000 \mathrm{Gal})$

\section{Conclusions}

On the basis of the nonlinear finite element analysis, we compare the seismic dynamic damage characteristics of vertical and batter pile-supported structures under the same construction site, service, and geological conditions. The results are as follows:

(1) The effect of the maximum displacement under the same ground motion on the batter pile-supported structure is smaller than that on the vertical pile structure. According to the calculation results of the dynamic time history response analysis, the maximum displacement of the vertical pilesupported structure is more than two times of the batter pilesupported structure.

(2) Under the two different types of seismic ground motions, the batter piles in the batter pile-supported structure play a dominant role in bearing the seismic load. Therefore, the vertical piles near the sea side do not approach the plastic area, plastic hinge does not occur. By contrast, all piles in the vertical pile-supported structure enter the plastic area or reach full plasticity, and plastic damage occurs.

(3) The axial tension and pressure in batter piles play a major role in the batter pile-supported structure. Under the same ground motions, the moment value in the batter pilesupported structure is thus smaller than that in the vertical pile-supported structure. The moment in the vertical pilesupported structure also plays a dominant role, and the variation range of the value is larger than that of the batter pile-supported structure.

(4) Under ground motion with a PGA of $350 \mathrm{Gal}$, all piles in the batter pile-supported structure remain in the elastic stage, whereas the batter piles exceed the tensile limit. The responses of the three vertical piles near the land side in the vertical pile-supported structure enter into the plastic stage. Therefore, under the seismic ground motion of this level and in consideration of the horizontal displacement to be satisfied by the design requirement, the seismic performance of the batter pile-supported structure is better than that of the vertical pile-supported structure.

(5) Under ground motion with a PGA of $1000 \mathrm{Gal}$ and on the basis of the comparison of the damage process and the $M-\Phi$ hysteresis curve of the two structure systems, the vertical pile-supported structure has enough capacity for plasticity development to absorb and dissipate seismic energy compared with the batter pile-supported structure. Therefore, under the seismic ground motion of this level, the seismic performance of the vertical pile-supported structure is superior to that of the batter pile-supported structure.

\section{Acknowledgements}

This study was supported by the National Natural Science Foundation of China (No.51078033 and No.51178045).

\section{References}

1. Liu, H. X., "Tangshan earthquake". Beijing: Earthquake Publish Company, 1986.

2. Mondal, G., Rai, D. C., "Performance of harbour structures in Andaman Islands during 2004 Sumatra earthquake". Engineering Structures, 30, 2008, pp. 174-182.
3. Professional Standard of the People's Republic of China, "JST1462012 Code for Seismic Design of Water Transport Engineering". Ministry of Transport of the People's Republic of China, 2012. 
4. Shafieezaedeh, A., Desroches, R., Ramanathan, K., "Developing fragility curves for a typical pile-supported wharf structure". ECCOMAS Thematic Conference - COMPDYN 2011: 3rd International Conference on Computational Methods in Structural Dynamics and Earthquake Engineering: An IACM Special Interest Conference, Programme, 2011.

5. Wang, G. S., Huang, F. K., Huang, C. L., "Seismic fragility analysis framework for pile-supported wharf". Proceedings of the International Offshore and Polar Engineering Conference, 2011, pp. 516-523.

6. Jaradat, O. A., Priestley, M. J. N., "Displacement-based procedures for seismic design of pile-supported wharvesat the port of Los Angeles and the port of Long Beach". American Concrete Institute, ACI Special Publication, 295, 2012, pp. 42-61.

7. Shafieezadeh, A., Kosbab, B. D., Desroches, R., Leon, R. T., "Dynamic interaction behavior of pile-supported wharves and container cranes in liquefiable soil embankments". Structures Congress 2012 - Proceedings of the 2012 Structures Congress, 2012, pp. 549-558.

8. Thomopoulos, C., Lai, C. G., "Preliminary definition of fragility curves for pile-supported wharves". Journal of Earthquake Engineering, 16(SUPPL. 1), 2012, pp. 83-106.

9. Elahi, H., Poulos, H. G., Moradi, M., Ghalandarzadeh, A., "Seismic analysis of pile group in soil slopes using pseudostatic approach". Geotechnical Special Publication, 225, 2012, pp. 2273-2282.
10. Amirabadi, R., Bargi, K., Torkamani, H. H., "Seismic demands for pile-supported wharf structures with batter piles". Research Journal of Applied Sciences, Engineering and Technology, 4(19), 2012, pp. 3791-3800.

11. Shafieezadeh, A., DesRoches, R., Rix, G. J., Werner, S. D., "Seismic performance of pile-supported wharf structures considering soil-structure interaction in liquefied soil". Earthquake Spectra, 28(2), 2012, pp. 729-757.

12. Shafieezadeh, A., DesRoches, R., Rix, G. J., Werner, S. D., “Threedimensional wharf response to far-field and impulsive near-field ground motions in liquefiable soils". Journal of Structural Engineering (United States), 139(8), 2013, pp. 1395-1407.

13. Amirabadi, R., Bargi, K., Dolatshahi, P. M., Heidary, T. H., Mccullough, N., "Determination of optimal probabilistic seismic demand models for pile-supported wharves". Structure and Infrastructure Engineering, 10(9), 2014, pp. 1119-1145.

14. Heidary, T., H., Bargi, K., Amirabadi, R., McCllough, N. J., "Fragility estimation and sensitivity analysis of an idealized pilesupported wharf with batter piles". Soil Dynamics and Earthquake Engineering, 61-62, 2014, pp. 92-106.

15. Ramirez-Henao, A. F., Paul Smith-Pardo, J., "Elastic stability of pile-supported wharves and piers". Engineering Structures, 97, 2015, pp. 140-151.

16. Japan Road Association. "Specifications for Highway Bridges Part IV Substructures”, 2012, pp. 284-287.

17. Anil, K. C., "Dynamics of Structures: Theory and Applications to Earthquake Engineering, 2/e". Pearson Education Asia Limited and Tsinghua University Press, 2005, pp. 124-139. 